УДК 881.111 ' $42: 659$ (043.5)

DOI https://doi.org/10.52726/as.humanities/2021.3.16

\author{
Н. О. ВАСИЛЬСВА \\ кандидат філологічних наук, \\ в. о. доиента кафедри англійської філології, \\ Чорноморський наиіональний університет імені Петра Могили, м. Миколаїв, Украӥна \\ Електронна nошта: nadezhdavasylieva@gmai.com \\ http://orcid.org/0000-0002-7926-3334
}

\title{
ДО ПИТАННЯ ВЗАЄМОДІЇ ПРАГМАТИКО-ЛІНГВІСТИЧНИХ РИС ПОЛІКОДОВИХ ТЕКСТІВ АНГЛОМОВНОЇ СОЦІАЛЬНОЇ РЕКЛАМИ
}

У статті проаналізовано проблему взаємодії семіотичних знаків, вербальних одиниць і прагматичних інтенцій автора на матеріалі полікодових текстів сучасної англомовної соціальної реклами. Рекламне повідомлення інтерпретується як структурно та логічно завершений письмовий текст, створений із певною метою. Як відомо, рекламне повідомлення соціальної тематики, на відміну від комерційного, порушує важливі питання і створюється для гуманізації суспільства. 3 позиції лінгвістики рекламний текст вважається негомогенним, тобто таким, що поєднує вербальний (мовний або мовленнєвий) і невербальний (містить одиниці, що належать до інших знакових систем) елементи. Враховуючи складну природу поняття «полікодовий тест», ми застосували класифікацію знаків Ч. С. Пірса на семантичному, синтаксичному і прагматичному рівнях пізнання та елементи прагматично-лінгвістичного аналізу для дослідження дібраних рекламних повідомлень.

У результаті вивчення ілюстративного матеріалу було визначено, що кожне рекламне повідомлення акумулює низку знаків (іконічні, індексальні, символічні), котрі прямо чи опосередковано вказують на об'єкт або проблему, якій присвячена реклама. Показово, що ключову роль у відібраних полікодових текстах відіграє візуальний компонент (обрана кольорова палітра, графічні засоби, фотомонтаж, колаж тощо), а вербальний компонент (судження або висновок) лаконічно резюмує представлену соціальну проблему.

Автори рекламних повідомлень звертаються до різних лінгвістично-стилістичних засобів (на фонетичному, лексичному, синтаксичному рівнях) для досягнення поставленої мети. При цьому знаки та лексико-стилістичні засоби гармонійно доповнюють одне одного, оптимізуючи текст соціальної реклами.

Ключові слова: рекламний текст, полікодовий текст, лінгвістика, прагматика, семіотика.

Постановка проблеми. Наразі феномен реклами $є$ багатоаспектним явищем, тобто соціальним, естетичним, культурологічним, економічним і маркетинговим, психологічним, прагматичним, семіотичним, когнітивним, лінгвістичним. Це явище цікавить спеціалістів різних галузей та надає можливості для дослідження нових «граней» реклами.

Рекламний текст привертає увагу мовознавців, які використовують різноманітний фактологічний матеріал та підходи до аналізу: структурну організацію реклами (I. О. Морозова, І. В. Городецька, Л. М. Макарук та інші), дослідження реклами на фонетичному, лексичному, синтаксичному, надфразовому рівнях (О. І. Зелінська, С. А. Федорець, С. В. Мощева та інші), рекламу у загальнолінгвістичних студіях (Дж. Даєр, К. Бове, А. О. Малишенко, О. В. Іванців, В. В. Зірка [Зірка 2010 : 166-180], С. К. Топачевський, В. В. Лєдньова, Л. В. Дубовицька та інші). Однак, попри численні публіка- ції та розвідки, дослідження тексту рекламного повідомлення все ще не має системного характеру. Саме тому вивчення семіотичних та прагматико-лінгвістичних нюансів англомовної соціальної реклами є актуальним і доречним.

Аналіз попередніх досліджень. Середкалейдоскопу трактувань нам імпонує позиція дослідниці Є. В. Медвєдєвої, котра розуміє рекламу як «різновид масової комунікації, в якому створені та поширені інформативно-образні, експресивно-сугестивні тексти односпрямованого і неособистого характеру, оплачені рекламодавцем і адресовані групам людей з метою спонукання їх до потрібних рекламодавцю вибору і вчинку» [Медвєдєва 2003 : 16-17].

Рекламний текст, або повідомлення, як і будь-який текст, має письмову форму, є змістовно і структурно закінченим, а також містить авторську позицію щодо самого повідомлення [Лосєва 1980 : 4]. Крім цього, у ньому містяться вербальні (лінгвальні) та невербальні (пара- 
лінгвальні) структурні компоненти, котрі відрізняють його від традиційного тексту. Тобто рекламний текст акумулює не тільки лексику, а й семіотичні коди та знаки різних рівнів ${ }^{1}$.

За Ч. С. Пірсом, знак - це абстрактний і матеріальний об'єкт, що представляє у підсвідомості інший об'єкт чи поняття [Пірс 2001 : 170; Тумакова $2016: 43-44]$. Науковець розмежовує знаки на семантичному, синтаксичному і прагматичному рівнях. На семантичному рівні (інтерпретація знаків і їх поєднання) існують такі знаки: іконічний знак (має подібність до об'єкта), індексальний знак (вказує на референта за допомогою різних засобів), символічний знак (представляє умовний зв'язок із референтом). На синтаксичному рівні (логіко-структурний взаємозв'язок знаків) вирізняються такі знаки: якісні (вказують на якості предмета), одиничні (наголошують на унікальності) та загальні (представляють нормативні ознаки об'єкта). На прагматичному рівні (зв'язок знаків з інтерпретатором) є такі елементи: рема, судження та умовивід / висновок. Показово, що висновок / умовивід формує поєднання реми й судження [Пірс 2001 : 172].

У лінгвістиці рекламний текст називають по-різному: креолізований, полікодовий, мультимодальний, семіотично ускладнений, відеоварбальний, гібридний тощо, оскільки вчені звертаються до вивчення численних аспектів рекламного повідомлення. Однак найбільш влучним, на нашу думку, є прикметник «полікодовий», котрий застосували Г. В. Ейгер та В. Л. Юхт у 1974 р. для тлумачення опозиції «монокодовий текст - полікодовий текст», останній $з$ яких вказує на «діапазон» цього поняття: «< .. > до полікодових текстів у широкому семіотичному сенсі повинні бути віднесені випадки поєднання природного мовного коду 3 кодом будь-якої семіотичної системи (зображення, музика тощо)» [Ейгер, Юхт 1974 : 50]. Зазначимо, що термін «полікодовий текст» широко використовується поряд із термінами «креолізований» $\mathrm{i}$ «мультимодальний» у працях А. О. Бернацької, Л. С. Большакової, Л. М. Большиянової, О. Г. Соніна, К. О. Уваро-

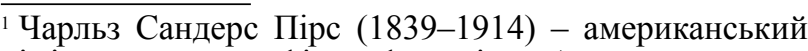
хімік, математик, філософ, логік; обгрунтував принципи семіотики та розробив трихотомію знаків, базуючись на критерії зв'язку знаку та об'єкта, який ним представлений.
}

вої, Є. А. Єліної, Д. П. Чигаєва та інших дослідників [Тумакова 2016 : 44; Шикіна 2018 : 352].

Мета статті полягає в аналізі взаємодії семіотичних, прагматичних та лінгвістичних особливостей на матеріалі англомовного тексту соціальної реклами.

Виклад основного матеріалу. Матеріалом наукової розвідки є 100 текстів англомовної соціальної реклами (постери), котрі ми розглядаємо як полікодові, що знаходяться у вільному доступі в Інтернеті. Проаналізувавши коло проблем вибірки, ми виділили такі тематичні групи:

1) питання навколишнього середовища 39 одиниць (Plastic Bags Kill. Keep The Ocean Clean; Fashion Claims More Victims than You Think; How Does It Feel?);

2) насилля та війна - 16 одиниць (Unhate; Words Kill Wars; Silence Hurts; When He Controls Your Life, It's No Longer Your Life);

3) здоров'я людини - 13 одиниць (Save Lives. Stub It Out; Smoking Causes Premature Ending; Causing Cancer By Yourself);

4) безпеки на дорозі - 10 одиниць (Don't Drink and Drive; Think of Both Sides; Buckle Up. Stay Alive);

5) проблеми соціально незахищених груп людей - 8 одиниць (Indifference Kills; Over 30\% of All Suicides Are Committed by Senior Citizens; Your Skin Colour Shouldn't Dictate Your Future);

6) розвінчування соціальних стереотипів 2 (You're Not a Sketch. Say No to Anorexia).

Розглянемо більш детально особливості рекламного повідомлення на матеріалі найбільш показових прикладів за допомогою трихотомії знаків Ч. С. Пірса і прагматико-лінгвістичного підходу до аналізу з урахуванням особливої структури рекламного повідомлення.

Соціальна реклама першої групи вражає різноманіттям репрезентації глобально важливих питань. Через специфічність і мету такої реклами автори звертаються до логіки й фактів (статистики, експертних висновків і суджень) та безпосередньо до емоцій реципієнта, часто використовуючи неприємні або відверто відразливі візуальні образи, що викликають почуття страху, неминучої катастрофи, провини, відповідальності аудиторії, а також спонукають до переоцінки ситуації та зміни моделей поведінки. Саме тому більшість із розглянутих рекламних постерів фокусує увагу на зобра- 


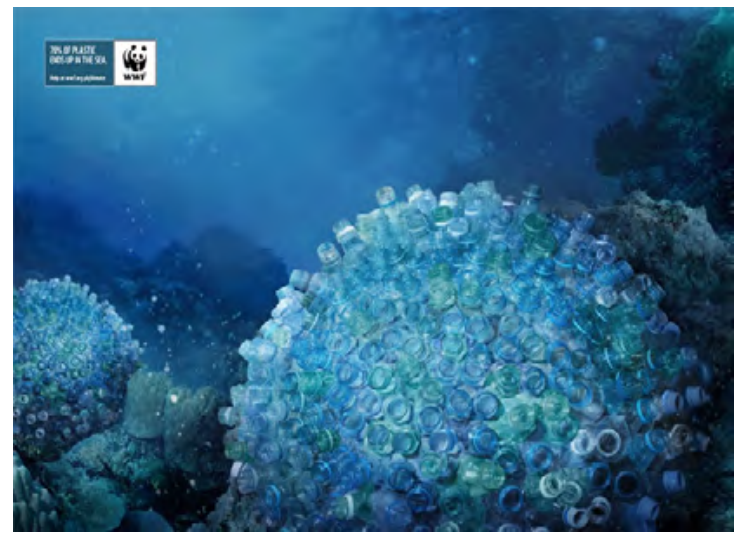

Puc. 1. 70\% of Plastic Ends Up in the Sea

Група 1. Питання навколишнього середовища

женні, а не на вербальній складовій частині, що подається дрібним, ледь помітним шрифтом вгорі або внизу повідомлення.

Рекламне повідомлення на рис. 1 містить іконічний знак - фотографію морського дна, на передньому плані якої зображено кулясту купу пластикового сміття, що ніби вже стала частиною екосистеми. У верхньому лівому кутку фотографії є логотип компанії у вигляді тварини (панди), що символізує Всесвітній фонд природи, котрий ми розуміємо як знак-символ. Поруч розміщений вербальний код, представлений у вигляді наведених статистичних даних: "70\% of Plastic Ends Up in the Sea" («70\% пластику опиняється в морі»)2.

Подібну до першого прикладу структуру має рекламне повідомлення на рис. 2: іконічний знак подано у вигляді малюнку автівки, що втратила керування і летить у прірву; знаксимвол (ідентифікатор) представлено назвою фірми "Јеер"; судження, представлене вербально, - це риторичне запитання, котре застерігає щодо фатальних наслідків недбалого ставлення до навколишнього середовища: "If There Is NO Planet, Where Will You Drive?” («Якщо не буде планети, куди ти поїдеш?»). Показово, що кольорова палітра графічної складової частини реклами підібрана відповідно до заявленої теми - синьо-зелені відтінки, що символічно звертаються до питання екології.

На рис. 3 та 4 представлено соціальну рекламу на тему насилля і війни. Вдалий вибір фотографії на рис. 3 ілюструє складну соціальну

\footnotetext{
${ }^{2}$ Цей та всі наступні переклади вербальних компонентів рекламних повідомлень 3 англійської мови виконано автором.
}

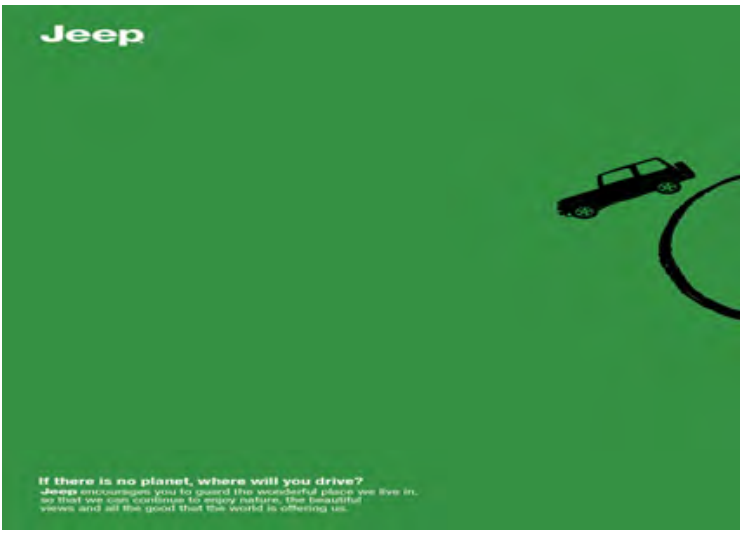

\section{Puc. 2. If There Is NO Planet, Where Will You Drive?}

Група 1. Питання навколишнього середовища

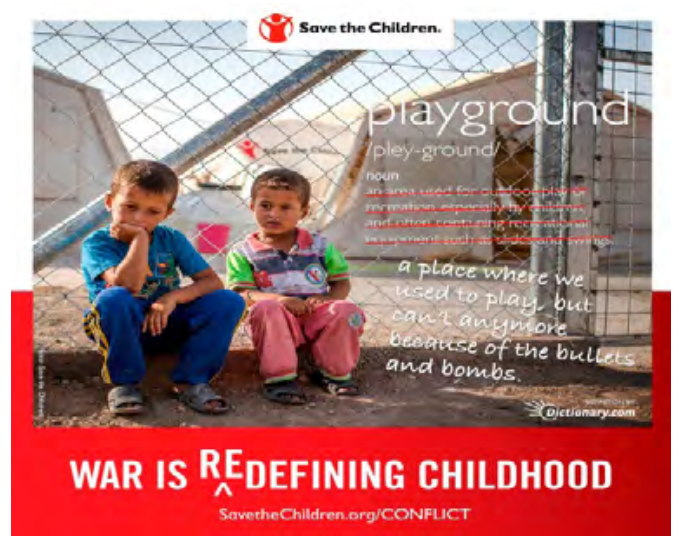

Puc. 3. War Is Redefining Childhood

Група 2. Питання насилля та війни

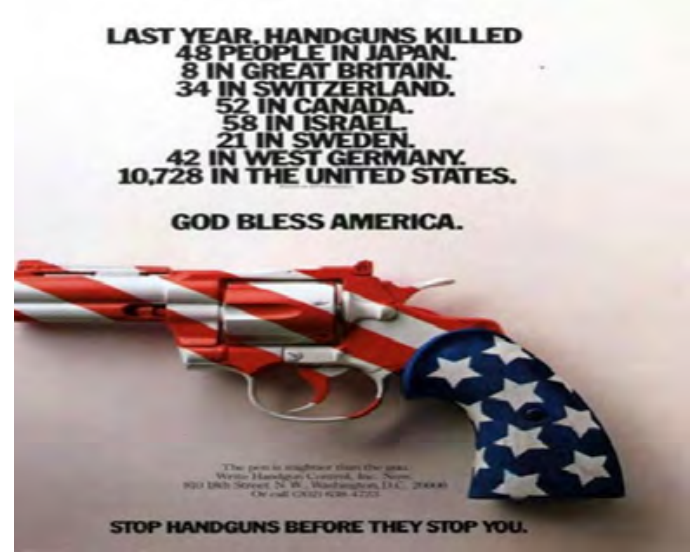

Puc. 4. Stop Handguns Before They Stop You

Група 2. Питання насилля та війни

ситуацію - дитинство в умовах війни (про це свідчать пози задумливості героїв, розгублений вираз обличчя одного із дітей, сумний погляд, перебування хлопчиків поблизу обгороджених 


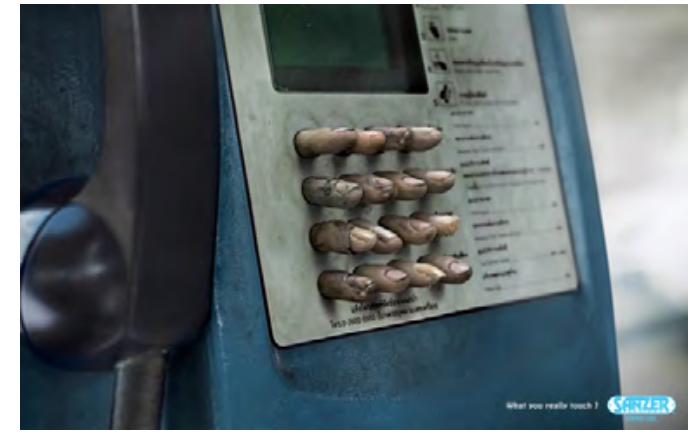

Pис. 5. What you really touch?

Група 3. Питання здоров'я людини

сіткою наметів, відсутність іграшок). Фото сумних дітей - індексальний знак. Крім цього, ліворуч від дітей винесено дрібним шрифтом словникову дефініцію поняття «ігровий майданчик» (playground), показово перекреслену червоною горизонтальною лінією: “an area used for outdo play or recreation, especially by children, and often containing recreational equipment such as slides and swings" («місце, що використовується для вуличних ігор або відпочинку дітьми, де часто розміщені гойдалка та гірка»). Далі іншим шрифтом, наближеним до почерку дитини: “ $a$ place where we used to play but can't anymore, because of the bullets and bombs" («місце, де ми колись грались, але зараз не можемо через кулі та бомби»). Автори представляють судження (висновок), застосовуючи графічні засоби (іншим шрифтом на червоному тлі): “War Is Redefining Childhood” («Війна дає нове визначення дитинству»), при цьому у слові "redefining” префікс “re" виділено особливою позначкою, котра вказує на зміну у трактуванні поняття «дитинство». Крім вербальних і графічних елементів, вгорі постеру розміщений символічний знак (людський силует червоного кольору), який вважається символом міжнародної неурядової організації "Save the Children".

На рис. 4 представлено полікодовий текст, що має резонансний характер завдяки поєднанню візуальних, графічних i вербальних елементів. У центрі фотографії розміщені два ключових символи - зброя і прапор. Обидва знаки-символи мають стійкі асоціації: перший ототожнюється із насиллям і страхом, другий - 3 державною владою, захистом і стабільністю. Проте у такій комбінації візуальних образів представлене фото $є$ індексальним знаком, що вказує на об'єкт (проблему легалізації

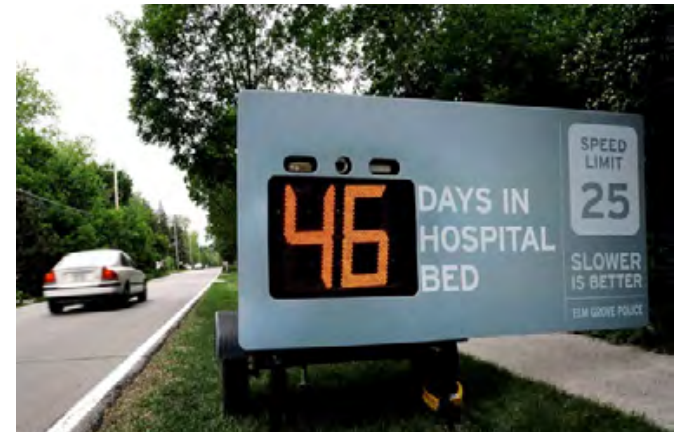

Рис. 6. Slower is better

Група 4. Питання безпеки на дорозі

зброї у США) у метафоричному вигляді. Що стосується вербального компонента, то над фото представлена статистика вбивств серед цивільного населення в різних країнах: “Last year, handguns killed 48 people in Japan, 8 in Great Britain, 34 in Switzerland, 52 in Canada, 58 in Israel, 21 in Sweden, 42 in West Germany, 10,727 in the United States. God bless America." («Із короткоствольної зброї було вбито 48 людей у Японії, 8 у Великій Британії, 34 у Швейцарії, 52 у Канаді, 58 у Ізраїлі, 21 у Швеції, 42 у Західній Німеччині, 10727 у Сполучених Штатах минулого року»). Автор рекламного тексту звертається до фактів, підтверджуючи, що для американського суспільства легалізація зброї має катастрофічні наслідки. Однак наступне твердження - "God bless America" - можна інтерпретувати по-різному: 1) як алюзію на відому американському слухачеві однойменну пісню ${ }^{3}$; 2) як алюзію на однойменний фільм ${ }^{4}$; 3) як звернення до Бога у молитві; 4) як в'їдливу іронію або ж сарказм. Під фотографією подана основна думка (висновок): "Stop handguns before they stop you" («Зупини зброю поки вона не зупинить тебе»); де на лексичному рівні було повторене дієслово "stop", використані особові займенники "they" - "you”, перший з яких стосується зброї, а інший вказує на людину; на лексико-стилістичному рівні була застосована метафора "handguns $<$... > stop you".

Рекламний текст на рис. 5 присвяченій темі здоров'я людини. На фотографії у блідих відтінках синьо-сірого кольору зображений таксофон із людськими пальцями замість кно-

\footnotetext{
${ }^{3}$ Американська патріотична пісня написана у 1918 р. І. Берліном під час проходження військової служби у США.

${ }^{4}$ Американський сатиричний фільм 2011 р., в якому піднімаються гострі соціальні питання сучасного суспільства.
} 


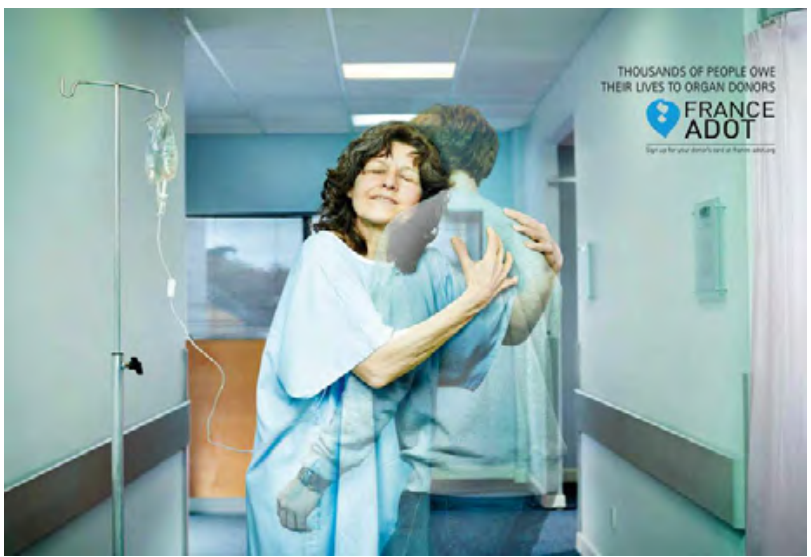

Puc. 7. Thousands of people owe their lives to organ donors

пок. Представлений образ є метонімією, в якій кнопки номерів телефону замінено брудними фалангами пальців різних осіб, ймовірно, небезпечними для фізичного контакту. Ця відразлива візуалізація проблеми привертає увагу, викликає низку асоціацій у свідомості людини та $є$ знаком-індексом. Ледь помітною, але не менш важливою $є$ вербальна складова частина повідомлення: “What you really touch?” («До чого ти реально торкаєшся?») - це риторичне питання, котре змушує реципієнтів задуматися про міри гігієни у публічних місцях. Поруч розміщений символічний знак - емблема компанії, що займається виробництвом антисептиків і пропагує здоровий спосіб життя.

Цікавим є рекламний текст на рис. 6, що звертається до проблеми безпечної поведінки водіїв транспортних засобів на дорозі. На постері фотографія зі щитом, в центрі якого написано: "46 days in hospital bed” («46 днів на лікарняному ліжку»). Імовірно, це середньостатистична кількість днів, необхідна для лікування особи, що потрапила у ДТП. Праворуч із використанням іншого шрифту на контрастному білому тлі зазначене обмеження швидкості для автомобілів на певній ділянці: “Limit speed 25 ”, а також основна ідея соціальної реклами: "Slower is better" («Краще повільніше»). Представлений текст на семантичному рівні містить іконічний знак (фотографію щита), що символізує захист. На прагматичному рівні очевидним $\epsilon$ протиставлення цифр (46 та 25) та судження "Slower is better".

До групи інших соціально важливих питань ми віднесли необ'єднані однією темою

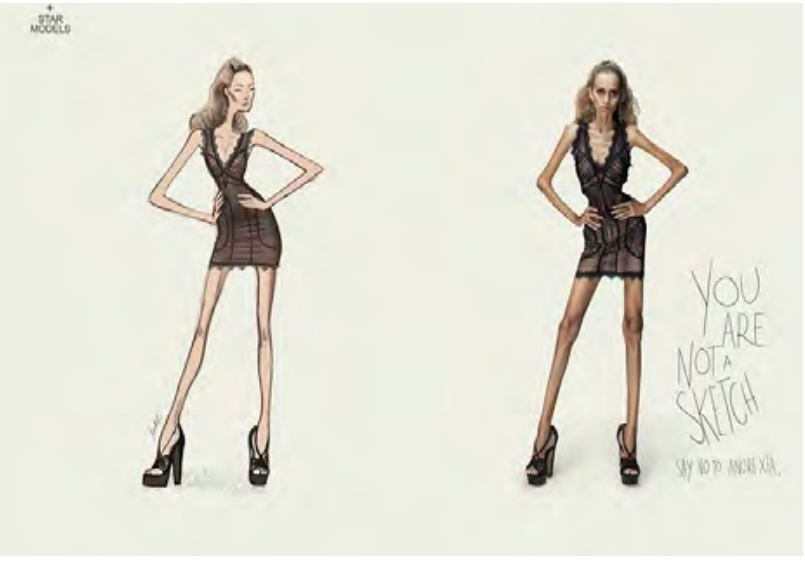

\section{Рис. 8. You're not a sketch. Say no to anorexia}

рекламні повідомлення (див. рис. 7, 8), які були створені за подібною схемою: у центрі уваги індексальні знаки, котрі опосередковано вказують на порушене питання; символічний знак, що співвідноситься із громадською організацією, представлений логотипом/емблемою; вербальна складова - судження або висновок подана, як правило, контрастним шрифтом або, навпаки, ледь помітним пунктиром, іншим розміром тощо.

Що стосується вербального компонента рекламних текстів на рис. 8, 9 "Thousands of people owe their lives to organ donors" («Тисячі людей завдячують своїм життям донорам») та "You're not a sketch. Say no to anorexia" («Ти не малюнок. Скажи «ні» анорексії»), то зазначимо таке:

у першому випадку спостерігаємо узагальнений факт щодо важливості донорства органів, з яким складно не погодитись. Судження представлене у формі розповідного речення;

у другому випадку основна думка представлена двома реченнями, одне 3 яких є імперативом, закликом до дій. На лексичному рівні застосовується повторення частки "not” ("no") для підсилення ефекту, а також вживання займенника “уои”, що апелює до аудиторії.

Висновки. Отже, у ході розвідки було з'ясовано, що інтерпретація полікодових текстів вимагає аналізу всіх елементів повідомлення на різних рівнях, адже вони, ніби фрагменти пазлів, гармонічно доповнюють одне одного, створюючи яскравий i семіотично ускладнений образ. Автори соціальної реклами комплексно застосовують різноманітні при- 
йоми на вербальному та візуальному рівнях для отримання необхідного ефекту. 3 огляду на це застосування вербальних та невербальних знаків разом має істотне прагматичне значення.

Що стосується текстів соціальної реклами, то ключовим $\epsilon$ парадоксальний візуальний образ (реальне фото, малюнок, комп'ютерний монтаж, колаж тощо), який співвідноситься із порушеною проблемою прямо чи опосередковано, а судження / головна думка узагальнює те, що представлене візуально. Вербальний компонент реклами містить лексичні повторення, використання займенників, заперечних часток, залучення наказових речень як суджень, залучення статистичних вибірок, фактів і аргументів, використання різнопланових стилістичних засобів, риторичних запитань, обірваних речень, силогізмів, алюзій тощо. Вважаємо, що завдяки такій какофонії графічних і вербальних креативних прийомів соціальна реклама набуває потужності, емоційності та експресивності і виконує свою головну функцію - гуманізацію сучасного суспільства.

Вважаємо доцільним використання семіотичного та прагматично-лінгвістичного підходів під час роботи із текстами, що мають негомогенну структуру, адже комплексний підхід до інтерпретації полікодового рекламного повідомлення є одним зі шляхів розуміння авторських інтенцій. Зокрема, за допомогою класифікації знаків Ч. С. Пірса [Пірс $2001: 166]$ вдалось розмежувати знаки на різних рівнях в межах полікодових текстів соціальної реклами.

Перспективу дослідження вбачаємо в аналізі перекладацьких стратегій рекламних повідомлень на матеріалі різних мов.

\section{ЛІТЕРАТУРА}

1. Ейгер Г. В., Юхт В. Л. К построению типологии текстов. Лингвистика текста : материалы научной конференции при Московском государственном педагогическом институте иностранных языков им. М. Тореза : в 2 частях. Ч. 1. Москва, 1974. С. 46-62.

2. Зирка В. В. Современная реклама : манипуляция с модными словами. Лінгвістика ХХІ століття : збірник наукових пращь. Серія «Нові дослідження і перспективи». Київ, 2010. С. 166-180.

3. Кохтев Н. Н. Стилистика рекламы : учебно-методическое пособие. Москва : Изд-во МГУ, 1991. 91 с.

4. Леонтьев А. А. Психолингвистические проблемы массовой коммуникации : монография. Москва : Наука, 1974. $147 \mathrm{c}$.

5. Лосева Л. М. Как строится текст : пособие для учителей. Москва : Просвещение, 1980. 94 с.

6. Медведева М. Е. Рекламная коммуникация. Москва, 2003. 160 с.

7. Тумакова Е. В. Креолизированный текст в художественном и медийном дискурсе. Мир русского слова. 2016. № 2. С. 43-49.

8. Пирс Ч. С. Элементы логики. Grammatica Speculativa: Семиотика : антология / сост. Ю. С. Степанов. Москва : Академический проект ; Екатеринбург : Деловая книга, 2001. С. 165-225.

9. Шикина Д. С. О терминах «поликодовость» и «креолизация» в описании рекламного текста глянцевых журналов. Вестник Московского государственного областного университета. 2018. № 2. С. 351-363.

\section{ДЖЕРЕЛА}

1. 40 Of The Most Powerful Social Issue Ads That'll make You stop And Think. URL: https://www.boredpanda.com/ powerful-social- advertisements/?utm_source=google\&utm_medium=organic\&utm_campaign=organic (дата звернення: 13.11.2021).

2. Best Examples of Social Advertising. URL: https://barrazacarlos.com/social-advertising-examples/ (дата звернення: 13.11.2021).

3. Social Advertising - Definition, Examples, Benefits and Platforms. URL: https://www.marketing91.com/socialadvertising/ (дата звернення: 22.11.2021).

\section{REFERENCES}

1. Yeyger G. V., Yukht V. L. (1974) K postroeniyu tipologii tekstov [To the texts typology construction]. Proceedings of Lingvistika teksta : materialy nauchnoy konferentsii pri Moskovskom gosudarstvennom pedagogicheskom institute innostrannykh yazykov im. M. Toreza v 2 chastyakh. (Russia, Moscow, 1974). Moscow, pp. 46-62.

2. Zirka V. V. (2010) Sovremennaya reklama : manipulyatsiya s modnymi slovami [The modern advertisement : manipulation with trendy words]. Zbirnyk naukovykh prats : Linhvistyka XXI stolittia : novi doslidzennia $i$ perspektyvy, vol. 3, pp. 166-180.

3. Kokhtev N. N. (1991) Stilistika reklamy [The advertising stylistics]. Moscow : Izd-vo MGU. (in Russian)

4. Lieont'ev A. A. (1974) Psikholingvisticheskie problemy massovoy kommunikatsii: [monografiya] [The Psycholinguistic problems of mass communication [monograph]]. Moscow : Nauka. (in Russian) 
5. Loseva L. M. (1980). Kak stroitsya tekst: posobie dlya uchiteley [How text is constructed : teachers' textbook ]. Moscow : Prosveshchenie. (in Russian)

6. Medvedeva M. E. (2003) Reklamnaya kommunikatsiya [The advertising communication]. Moscow. (in Russian)

7. Pierce Ch. S. (2001) Elementy logiki. Grammatica Speculativa [The elements of logics. Grammatica Speculativa]. Semiotika. Antologiya [Semiotics. Anthology]. Moscow : Akademicheskiy prospekt; Ekaterinburg: Delovaya kniga, pp. $165-225$.

8. Shikina D. S. (2018) O terminakh "polikodovost" i "kreolizatsiya" v opisanii reklamnogo teksta glyantsevykh zhurnalov [On the terms of 'polycodeness' and 'creolization' while describing advertising texts of glossy magazines]. Vestnik Moskovskogo gosudarstvennogo oblastnogo universiteta, no 2. pp. 351-363.

9. Tumakova E. V. (2016) Kreolizirovannyy tekst $\mathrm{v}$ khudozhestvennom i mediynom diskurse [The creolized text in artistic and media discourse]. Mir russkogo slova, no 2. pp. 43-49.

\title{
SOURCES
}

1. 40 Of The Most Powerful Social Issue Ads That'll make You Stop And Think. Retrieved from: https://www.boredpanda.com/powerful-social- advertisements/?utm_source=google\&utm_medium=organic\&utm_campaign=organic (accessed: 13.11.2021).

2. Best Examples Of Social Advertising. Retrieved from: https://barrazacarlos.com/social-advertising-examples/ (accessed: 13.11.2021).

3. Social Advertising - Definition, Examples, Benefits and Platforms. Retrieved from: https://www.marketing91. com/social-advertising/ (accessed: 22.11.2021).

\author{
N. O. VASYLIEVA \\ Ph. D. in Philology, \\ Senior Lecturer at the Department of English Philology, \\ Petro Mohyla Black Sea National University, Mykolaiv, Ukraine \\ E-mail: nadezhdavasylieva@gmai.com \\ http://orcid.org/0000-0002-7926-3334
}

\section{ON THE QUESTION OF PRAGMATIC AND LINGUISTIC PECULIARITIES INTERRELATION OF POLYCODE TEXTS OF ENGLISH SOCIAL ADVERTISING}

The problem of interrelation of semiotic signs, verbal units, and advertising specialists' pragmatic intentions on the material of polycode texts of English modern social advertisements has been analyzed in the article. An advertisement is understood as a written text which is structurally, logically concluded and created intentionally.

As known, social advertising, in contrast to a commercial one, touches upon essential matters and is made up for humanization of society. From a linguistic perspective, the advertisement is meant to be a nonhomogeneous structure. In other words, it combines verbal (lingual and communicative) and non-verbal (units which belong to different sign systems) elements. Taking into consideration complicatedness of the notion of a 'polycode text', it has been decided to combine Ch. S. Pierce's classification of cognitive signs on different levels (semantic, syntactic, and pragmatic) and pragmatic and linguistic analysis methodology for examination of the chosen advertisement texts.

As a result of data analyzing, it has been specified that each advertisement accumulates a set of signs (icons, indexes, and symbols) that indicates the problem to which the ad is dedicated in straightforward or indirect ways. It is revealing that within the chosen polycode texts the most important is a visual component (e.g., a preferred colour palette, graphic means, montage, collage, etc.) than a verbal one (a judgment or conclusion) that just recapitulates in brief a displayed social problem.

Apparently, authors of advertising texts make use of various lexical-stylistic devices (on phonetic, lexical, and syntactical levels) to meet the goals. The signs and lexical-stylistic means complement each other harmoniously enhancing the efficiency of the advertising message.

Key words: an advertising text, a polycode text, linguistics, pragmatics, semiotics. 